\title{
Navigating The Debt-Equity Decisions Of Financial Services Firms: Some Evidence From South Africa
}

\author{
Vusani Moyo, University of Venda, South Africa
}

\begin{abstract}
Empirical studies on the impact of regulation on the financial policies of banks have documented that unconstrained forward-looking banks with sufficient franchise value build and actively maintain capital buffers. This financing behaviour thus relegates the regulatory intervention to non-binding and of secondary importance. This study used a sample of 29 financial services firms listed on the Johannesburg Stock Exchange (JSE) during the period 2003 to 2012 to test for the validity of the market timing, pecking order and the dynamic trade-off theories in explaining the financing behaviour of financial services firms. Consistent with the dynamic trade-off theory and contrary to the market timing and pecking order theories, the study documents that, leverage is positively correlated to firm profitability, size and asset tangibility. The firms' true speed of adjustment is $56.80 \%$ for the market-to-debt ratio $(M D R)$ and $71.31 \%$ for the book-to-debt ratio (BDR). The modified external finance-weighted average market-tobook has an insignificant positive and negative correlation with the MDR and the BDR respectively. Taken together, the JSE-listed financial services firms have target optimal capital structures which they actively adjust towards. Their security issuance decisions are not driven by the stock market performance, share returns or the time-varying adverse selection costs.
\end{abstract}

Keywords: Capital Structure; Trade-Off Theory; Pecking Order Theory; Speed of Adjustment; Random Effects Tobit; Blundell and Bond

\section{INTRODUCTION}

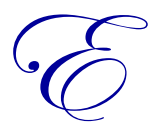

mpirical research on capital structure has always avoided using data from regulated financial services firms such as banks, building societies, insurance firms, medical aid schemes and investment firms in testing the validity of the leading capital structure theories. The main reason that is always cited is that these firms are regulated and have therefore different financial policies from the non-financial firms which are unregulated. The argument is that the regulatory framework imposes minimum capital requirements which has to be complied with if the firm is to continue operating. This argument implies that the financial policies of financial services firms are strictly dictated to by the existing regulatory regime and management have limited or no discretionary powers on the financial policies of their firms. This assertion, however, contradicts both the buffer capital theory of Marcus (1984) and Milne and Whalley (2001) and the theory of optimal bank capital structure of Flannery (1994), Myers and Rajan (1998), Diamond and Rajan (2000) and Allen, Carletti, and Marquez (2011) in the case of banks.

The buffer capital theory states that banks with low capital buffers strive rebuild an appropriate capital buffer whilst those with high capital buffers attempt to maintain them. The theory asserts that progressive banks with sufficient franchise value build and maintain a buffer of capital in excess of the regulatory minimum (Milne \& Whalley, 2001). The buffer capital is defined as the excess capital that a bank holds above the regulatory minimum and this results from the bank's discretionary financial policy (Lindquist, 2004). In the traditional capital structure theories, the buffer capital concept is equivalent to the firm's financial slack/flexibility as defined by the pecking order theory of Myers (1984) and Myers and Majluf (1984). Shivdasani and Zenner (2005) contend that firms place premium value on creating and maintaining financial flexibility as they view it as a real option to the firm. 
The theory of optimal bank capital structure asserts that the bank's optimal financial policy involves setting an optimal capital ratio which is the sum of the regulatory minimum and a capital cushion. This optimal capital ratio, which is a function of bank size, sanction costs, current capital ratio volatility, liquidity premium, operating costs variance, credit and liquidity risks, cash flow volatility and bank franchise value, maximises the value of the banking firm (Barrios \& Blanco, 2003:1955; Milne \& Whalley, 2001).

According to Berger, De Young, Flannery, Lee and Oztekin (2008), banks have capital ratios that are substantially above the regulatory minima; they actively manage their capital ratios and the negative target deviation spread is eliminated fairly quickly implying a relatively high speed of adjustment (SOA) towards the optimal capital structure. A number of studies including those of Barrios and Blanco (2003), Heid, Porath and Stolz (2004), Lindquist (2004), Octavia and Brown (2008), Rime (2001) and Shrieves and Dahl (1992) validate the buffer capital and optimal bank capital structure theories.

The capital adequacy ratios reported by the three major South African banks for the year ended 2013 also validate the buffer capital theory. For example, for the year ended 2013, the First Rand group's Common Equity Tier 1 (CET 1), Tier 1 and Total Capital adequacy ratios were 13.8\%, 14.8\% and 16.3\% respectively (First Rand Group, 2013). The Nedbank group's capital adequacy ratios were 12.5\%, 13.6\% and 15.7\% (Nedbank Group, 2013) while the Standard Bank group had capital adequacy ratios of 12.6\%, 13.2\% and 16.2\% (Standard Bank Group, 2013). In all cases, all the three capital adequacy ratios were well-above the SARB's minimum regulatory requirements of $4.5 \%$ for CET $1,6.0 \%$ for Tier 1 and $9.5 \%$ for the Total Capital adequacy ratio.

What informs the buffer capital policy? There are a number of reasons why the observed bank financing behaviour validates the buffer capital theory. Furfine (2001), Lindquist (2004:494) and Milne and Whalley (2001) argued that buffer capital ensures that the bank avoids costs related to market discipline and supervisory intervention that result from the infringements of minimum capital regulatory requirements. The cushion or excess capital reduces the probability that shocks may cause the capital ratio to fall below the regulatory minimum (Barrios \& Blanco, 2003). It serves as insurance against failure to meet minimum regulatory capital requirements (Heid et al, 2004). According to Rime (2001), the buffer capital eases the bank's regulatory pressure and reduces its risk. The banks also hold excess capital so that they are able to exploit unexpected investment opportunities (Berger, Herring \& Szgo, 1995).

The capital structure buffer and the optimal bank capital structure theories have a number of implications for the regulated financial firms. Firstly, these firms, like some of their unregulated non-financial counterparts, value financial flexibility. Secondly, the firms have an optimal capital structure where firm value is maximised. Thirdly, even though the firm's capital structures are regulated, they exercise their own discretion in their financial policies. This means that regulated firms relegate the regulatory requirements to non-binding and of second order importance. They design their own capital structures which maximise their firm values. This financing behaviour therefore invalidates the regulatory minimum capital theory that banks hold minimum capital to satisfy regulatory requirements. Fourthly, the firms are expected to actively rebalance their capital structures towards the optimal capital structure and this implies a positive SOA towards the target optimal capital structure. Owing to the costs of market discipline, the SOA towards the target optimal capital structure is expected to be higher than that of the unregulated non-financial firms. These implications raise the following questions about the financing behaviour of regulated firms: how do these firms choose their optimal debt to equity ratios? Can their financing behaviours be explained by the existing capital structure theories? How fast do these firms adjust their capital structures towards the optimal debt ratio?

A limited number of studies have attempted to explain the capital structures of banks using the trade-off and pecking order theories. The main studies include those of Amidu (2007), De Wet (2014), Gropp and Heider (2010), Lim (2012) and Octavia and Brown (2008). These studies have however been limited to banking firms thus excluding other regulated financial firms. They also exclude the test for the validity of the market timing in regulated financial services firms. Furthermore, these studies only used the pooled ordinary least squares (OLS) and fixed effects estimators. They shunned the modern and least biased econometric panel data estimators such as the AndersonHsiao (1981) instrumental variables, the difference generalised method of moments (GMM) of Arellano and Bond 
(1991), the system GMM of Blundell and Bond (1998), the random effect Tobit and the bias-corrected least squares dummy variable (LSDV) proposed by Bruno (2005).

The current study was aimed at addressing the short comings of the earlier studies on the determinants of the capital structure of financial services firms. Using a panel data set obtained from a sample of 29 financial services firms listed on the JSE during the period 2003 to 2012, the study tested for the validity of the market timing, pecking order and the dynamic trade-off theories in explaining the observed capital structures of financial services firms. The financial services firms sampled included banks, insurance, and investment and fund management firms. The study used the random effects Tobit estimator to fit the partial adjustment models. The study was also aimed at addressing the short comings of the earlier studies on bank capital structure.

As a preview of the results, the study found that the modified Bruinshoofd and De Haan (2012) market timing measure is positively correlated to the MDR ratio. The measure is however negatively correlated to the BDR ratio. The correlations are insignificant in all cases. Firm profitability, size, tangibility and growth rate all positively correlated to both the MDR and the BDR. The firms have a positive and significant SOA towards the optimal capital structure. The true SOA for the sample is $56.80 \%$ (half-life of 0.83 years) for the MDR and $71.31 \%$ (half-life of 0.56 years) for the BDR. The market timing measure has an insignificant effect in the MDR regression model but it increases the SOA towards the target leverage in the BDR regression model.

Except for the correlation between leverage and firm growth, these results are consistent with the dynamic trade-off hypothesis. They also validate the buffer capital and optimal bank capital structure hypotheses. The results however reject the market timing and pecking order theories. This means that the JSE-listed financial services firms have target optimal capital structures which they actively adjusts towards.

The rest of the paper proceeds as follows: Section 2 provides a review of the related literature and provides a basis for hypothesis development. Section 3 contains the data sources and methodology used. Section 4 discusses the results of the study, and Section 5 concludes the study.

\section{LITERATURE REVIEW AND HYPOTHESIS DEVELOPMENT}

According to Flannery and Rangan (2006) and Huang and Ritter (2009), the three leading theories that explain the observed corporate financing behaviour are the trade-off, pecking order, and market timing models. The trade-off theory asserts that firms have an optimal debt ratio where firm value is maximised. The optimal capital structure occurs at a point where marginal benefits of debt interest tax shields are equal to the marginal agency and financial distress costs (Modigliani \& Miller, 1963). The trade-off theory implies that the firms' financing decisions and hence the security issuance decisions are largely driven by the need to maintain an optimal capital structure. Byoun (2008) and Kayhan and Titman (2007) conceded that financing decisions are aimed at moving the firms towards their optimal capital structures. In practice however, it is observed that firms do deviate from their optimal capital structures but, regardless of the presence of adjustment costs, they actively rebalance their capital structures (Leary \& Roberts, 2005). This financing behaviour is consistent with the predictions of the dynamic trade-off theory of Fischer, Heinkel, and Zechner (1989), Goldstein, Ju and Leland (2001) and Hovakimian, Opler and Titman (2002). The rate at which the firm rebalances its capital structure defines its target SOA. According to Drobetz and Wanzernried (2006) and Hovakimian and Li (2011), the target SOA is affected by the firm-specific factors, the magnitude of the target deviation spread and the wider macroeconomic factors. Elsas and Florysiak (2011) documented heterogeneity across firms in the SOA towards the optimal capital structure. Moyo, Wolmarans \& Brümmer (2013) and Ramjee and Gwatidzo (2012) found that non-financial firms listed on the JSE have a positive SOA in the range of $42.44 \%$ to $65.00 \%$ on the MDR ratio and $57.64 \%$ to $74.44 \%$ on the BDR ratio. Thus according to the dynamic trade-off theory, firms have optimal leverage ratios which they actively rebalance towards at various speeds. The firms partially eliminate the target deviation spread and have a positive SOA towards the optimal capital structure.

The pecking order theory of Myers (1984) and Myers and Majluf (1984), which is based information asymmetry, rejects the idea of an optimal capital structure. The theory states that firms minimise their time-varying adverse selection costs by relying more on internal finance. If faced with an internal funds deficit, the firm follows a pecking 
order in raising external finance. This means that low risk debt being the first choice, then hybrid instruments and lastly equity (Barclay \& Smith, 2005; Tong \& Green, 2005). The pecking order minimises the firm's financing and information asymmetry costs thus maximising its value. The implication of the pecking order theory is that the observed debt ratios reflect the firm's cumulative requirement for external financing (Myers, 2008: 235). This contradicts the dynamic trade-off theory which states that observed leverage ratios reflects the firms attempt to move towards the optimal capital structure.

A number of studies including those of Elsas and Florysiak, 2011, Hovakimian and Li (2011), Huang and Ritter (2009), Leary and Roberts (2005) and Ramjee and Gwatidzo (2012) found that firms actively rebalance their capital structures towards the optimal capital structure thus validating the dynamic trade-off theory. The findings of Graham (2000), Lemmon and Zender (2010), Shyam-Sunder and Myers (1999), Titman and Wessels (1988) and Tong and Green (2005) support the pecking order theory. Some studies including those of Barclays and Smith (2005:9), Moyo et al (2013) and Mukherjee and Mahakud (2012), however, found the two theories to be complimentary in explaining the observed capital structures.

The market timing theory of Baker and Wurgler (2002), Korajczyk, Lucas and McDonald (1992) and Lucas and McDonald (1990) posits that managers time the equity market in making their security issuance decisions. Like the pecking order theory, the market timing theory is based on the existence of information asymmetry between managers and investors. The firm's decision to issue equity depends on the stock market performance and the current valuation of its shares. Firms only issue shares when they believe that the firm's shares are currently overvalued, otherwise they issue debt (Barclay \& Smith, 2005). Debt issuances signal that the firm's shares are undervalued (Spiess \& Affleck-Graves, 1999). According to Lucas and McDonald (1990), equity issuances are preceded by on average an abnormal positive share return and an abnormal rise in the market. According to Baker and Wurgler (2002), the effect of market timing is persistent, lasting more than 10 years. The marketing theory means that observed leverage ratios are reflected cumulative attempts by managers to time the equity market. The market timing theory rejects the idea of an optimal capital structure or the existence of a target optimal capital structure. According to the theory, firms do not rebalance their capital structures and hence the target SOA is zero. The sole determinant of corporate financing decision is over/undervaluation of securities. Interest tax shields, nondebt tax shield, agency and the time-varying adverse selection costs play no role in the security issuance decisions.

The support for the market timing theory is however mixed. Bongerdef and Chichti (2010), Burch, Christie and Nanda (2004), Elliott, Koeter-Kent and Warr (2008), Graham and Harvey (2001) and Jenter (2005) found that equity overvaluation drives equity issuance decisions and this validates the market timing theory. The findings of Alti (2006), Baxamusa (2011), Bruinshoofd and De Haan (2012), De Bie and De Haan (2007), Frank and Goyal (2004), Mahajan and Tartaroghi (2008) and Walker and Yost (2008), on the non-persistence of market timing effects however invalidates the market timing theory in, favour of the dynamic trade-off and pecking order theories. Both the dynamic trade-off and pecking order theories contend that the pricing of securities (over/undervaluation) and the performance of the stock market plays no role in the security-type issuance decisions if firms.

\subsection{The Market Timing Measures}

The study used the modified Bruinshoofd and De Haan's (2012) External Finance-Weighted Average Market-toBook $\left(E F W A M B_{t}^{B D}\right)$ market timing measure. The model only uses long-term debt as it accurately captures market timing of issuance decisions. Furthermore, this measure allows for direct interpretation of the regression results. The measure is defined as:

$$
E F W A M B_{t}^{B D}=\frac{1}{\overline{M B}} \sum_{s=1}^{t-1} \frac{e_{s}+l t d_{s}}{\sum_{r=1}^{t-1} e_{r}+l t d_{r}} \times M B_{S}
$$

Where $\overline{M B}$ is the average level of market-to-book ratio over each firm's entre sample period, 2003 to 2012; $e$ and $l t d$ denote net equity and total long-term debt issuances respectively; MTB is the market-to-book ratio, suffices $S$ represents a specific year issuances and suffice $r$ represents issuances for the total period. Baker and Wurgler (2002) define equity issuances as a change (increase) in the book value of share capital and debt issuances as a change (increase) in the book value of debt. $\frac{e_{s}+l t d_{s}}{\sum_{r=1}^{t-1} e_{r}+l t d_{r}}$ is the ratio of current period external finance to the total external 
finance over the study period which in this study is the years 2000 to 2012. The measure implies that firms that time the market tend to have a high $E F W A M B_{t}^{B D}$ since they issue more equity and less long-term debt when the MTB is high. The study also used the Baker and Wurgler's (2002) market timing measure to test for robustness of the results. The measure is defined as follows:

$$
E F W A M B_{t}^{B W}=\sum_{s=1}^{t-1} \frac{e_{S}+d_{s}}{\sum_{r=1}^{t-1} e_{r}+d_{r}} \times M B_{S}
$$

Where $d$ denotes total debt issuances.

\subsection{Firm-Specific Determinants of Leverage}

Following Baker and Wurgler (2002),Bruinshoofd and De Haan (2012), De Bie and De Haan (2007) and Mahajan and Tartaroghi (2008), the study's regression model also included a set of firm-specific determinants of leverage. These factors control for firm-specific effects and were also used to test for the mutual-exclusiveness of the dynamic trade-off, pecking order and market timing theories. These factors are part of the Frank and Goyal's (2009) core leverage model and are profitability, firm size, un-weighted market-to-book ratio and asset tangibility. From the stylised facts of Bessler, Drobetz and Kazemieh (2011), large firms and firms with considerable tangible assets tend to have high leverage. On the other hand, profitable firms and those that have high growth opportunities tend to have low leverage.

Firms with high growth rates tend to be young, less profitable and hence face lower tax bills (Dang, Kim \& Shin, 2012). The firms' high capital expenditures increases their non-debt tax shields in the form of capital allowances. The increased non-debt tax substitutes the benefit from debt interest as the two are perfect substitutes (De Angelo \& Masulis, 1980). Growth firms are therefore likely to suffer from increased financial distress and underinvestment costs (Myers, 1977). According to the trade-off theory, these costs can be reduced by using more equity than debt and hence a negative correlation between leverage and firm growth rate (Bessler, et al, 2011). By contrary, low growth firm tend to be large, mature, and highly profitable. They face increased tax bills which derive from their high profitability and low capital expenditures. The low growth firms are also likely to suffer from the agency costs of overinvestment which result from increased free cash flow (Jensen \& Meckling 1976). These costs can be reduced by using more debt. The study used $M T B$ ratio as a proxy for firm growth rate.

Asset tangibility is a direct measure of the collateral that the firm can offer to lenders (Bessler et al, 2011). Firms with high collateral assets face reduced bankruptcy costs which in turn increases the net benefits of debt to the firm. Furthermore, the increased collateral reduces the firms' borrowing costs while increasing their debt capacities. This makes borrowing more attractive to the firms and hence high leverage. Campello and Giambona (2013) found that asset tangibility and redeployability are the main drivers of corporate debt policy. The positive correlation between leverage and asset tangibility is consistent with the prediction of trade-off theory. Asset tangibility was measured as fixed assets scaled up with total assets.

Large firms tend to be mature, have stable earnings, less risky and have high stocks of tangible assets (Barclay \& Smith, 2005). These features increase their credit ratings thus making debt a cheaper and more attractive source of finance for them (Kisgen, 2007). Leverage is therefore negatively correlated to firm size and this validates the tradeoff theory. Firm size was measured as the natural logarithm of total assets.

According to the pecking order theory, profitable firms with sticky dividend policies face lower or no internal funds deficiency and hence will require less external finance which is raised in pecking order with debt being the first option (Myers, 2008). This financing behaviour implies that highly profitable firms use less debt finance. The negative correlation between profitability and leverage is consistent with the predictions of the pecking order theory. According to Myers (1984) and Myers and Majluf (1984) this negative correlation presents "the most telling evidence against the trade-off theory". In this study, profitability was measured by the ratio of earnings before interest, tax, depreciation and amortisation (EBITDA) to total assets. 
The inclusion of $M T B$ variable in the regression model was to also control for the cross-sectional variation in the level of market-to-book and this leaves only the residual influence of past, within-firm variation in the market-tobook ratio for the $E F W A M B_{t}^{B W}$. The study uses two measures of leverage: the MDR and the BDR. MDR is defined as the total interest-bearing debt (short-term and long-term) scaled up by the sum of the total debt and the firm market capitalisation. BDR is defined as the total interest-bearing debt (short-term and long-term) scaled up by the total assets.

\subsection{Hypotheses}

The hypotheses developed above can be summarised as follows:

Hypothesis 1: Market Timing Behaviour

Firms time the market in their debt-equity issuance decisions and do not consecutively rebalance their capital structures. Thus there is a significant negative correlation between leverage and the $E F W A M B_{t}^{B W}$. A significant negative correlation between leverage and $E F W A M B$ confirms that validity of the market timing theory whilst a positive correlation or insignificant negative correlation validates the static trade-off theory.

Hypothesis 2: Firm-specific Determinants of Leverage

Hypothesis 2.1: Leverage is negatively correlated to firm growth rate

Hypothesis 2.2: Leverage is negatively correlated to firm profitability

Hypothesis 2.1: Leverage is positively correlated to asset tangibility

Hypothesis 2.1: Leverage is positively correlated to firm size.

Hypothesis3: SOA towards Target Leverage

The market timing theory hypothesizes that firms do not have target leverage ratios and hence will have zero SOA.

\section{DATA AND METHODOLOGY}

The data for the study was drawn from a sample of 29 JSE-listed financial services firms with complete data for eight or more consecutive years during the period 2003 to 2012. The financial services firms listed on the JSE during this period included banks, investment firms and insurance firms. An unbalanced panel was constructed from data drawn from the McGreGorBFA's standardised annual financial statements of these firms. The total number of observations for the period was 290 .

\subsection{Regression Model}

This study follows the methodology used by Moyo (2014). Following Baker and Wurgler (2002), Bruinshoofd and De Haan (2012) and Mahajan and Tartaroglu (2008), the basic regression model was specified as:

$$
\begin{aligned}
& \operatorname{Lev}_{i, t+1}=\gamma_{1} E F W A M B_{t}^{B W}+\gamma_{2}\left(\frac{E B I T D A}{T A}\right)_{t}+\gamma_{3} \operatorname{Ln}(T A)_{t}+\gamma_{4}\left(\frac{F A}{T A}\right)_{t}+\beta_{5} M T B_{t}+c_{i}+ \\
& \varepsilon_{i, t+1}
\end{aligned}
$$

Where: $L e v_{i, t+1}$ is the firm's debt ratio measured by either the BDR or the MDR at $i, t+1$; $i$ denotes a particular firm; $t$ is the current year; $t+1$ is the next year; $\gamma_{1}, \gamma_{2}, \gamma_{3}, \gamma_{4}$ and $\gamma_{5}$ are coefficient vectors; $c_{i}$ denotes the firm fixed effect and $\varepsilon_{i, t+1}$ is an error term.In this study, $E F W A M B_{t}^{B W}$ was substituted by $E F W A M B_{t}^{B D}$ and the resulting model was specified as: 


$$
L e v_{i, t+1}=\gamma_{1} \boldsymbol{X}_{t}+\gamma_{2} E F W A M B_{t}^{B D}+c_{i}+\varepsilon_{i, t+1}
$$

Where $\boldsymbol{X}_{i, t}$ is a vector of the firm-specific variables contained in model 1.

According to the dynamic trade-off theory, firms have target debt ratios towards which they actively adjust at a given speed. The active adjustment towards a target debt ratio assumes a perfect capital market, which implies that firms will frequently and fully adjust to their chosen target ratios. However, in practice, firms face information asymmetries, transaction costs and adjustment costs, and this implies that they will infrequently and partially adjust their capital structures towards their predetermined leverage ratios. A firm's target leverage, $\operatorname{Lev}_{i, t+1}^{*}$, is given by:

$$
\operatorname{Lev}_{i, t+1}^{*}=\boldsymbol{X}_{i, t} \gamma
$$

Where $\gamma$ is a coefficient vector.

The firm's leverage partial adjustment model is specified as:

$$
L e v_{i, t+1}-L e v_{i, t}=\left(L e v_{i, t+1}^{*}-L e v_{i, t}\right)+\varepsilon_{i, t+1}
$$

Substituting (5) into (6) and simplifying the equation yields a partial adjustment model that can be used to estimate the firm's SOA towards the target leverage that is:

$$
L e v_{i, t+1}=(1-\lambda) L e v_{i, t}+\lambda\left(\boldsymbol{X}_{i, t} \gamma\right)+c_{i}+\varepsilon_{i, t+1}
$$

Where $\lambda$ denotes the SOA towards the target leverage and $c_{i}$ is the time-invariant unobserved variable (firm-fixed effect).

For the dynamic trade-off theory hypothesis to hold, some of the elements of the coefficient vector must be different from zero that is $\gamma \neq 0$. In cases where $\lambda=0$, it means that the SOA is zero implying that firms have no target leverage ratios. If $\lambda=1$, it means that the firm immediately adjusts towards its target debt ratio. It is also possible to get negative values of $\lambda$. The negative SOA means that the firm over-adjusts its leverage.

The partial adjustment model can be extended to include the market timing measure. The extended partial adjustment model is therefore:

$$
\operatorname{Lev}_{i, t+1}=(1-\lambda) L e v_{i, t}+\lambda\left(\boldsymbol{X}_{i, t} \gamma_{1}\right)+\lambda \gamma_{2} E F W A M B_{t}^{B D}+c_{i}+\varepsilon_{i, t+1}
$$

This is the basic regression model and is labelled regression model 1. The alternative partial adjustment model only uses the firm-specific variables with no market timing measures. This is expressed as:

$$
\operatorname{Lev}_{i, t+1}=(1-\lambda) \operatorname{Lev}_{i, t}+\lambda\left(\boldsymbol{X}_{i, t} \gamma\right)+c_{i}+\varepsilon_{i, t+1}
$$

This is regression model 2 .

The study used regression model 1 to test for the validity of the market timing and dynamic trade-off theories and to estimate the SOA towards the target leverage. Regression model 2 was used to test what impact excluding the market timing measure has on the firm's SOA towards the target leverage. The random effects Tobit maximum likelihood estimator was used to fit both regression models. This estimator is an equivalent of the double-censored dynamic panel data with a fractional dependent variable (DPF) estimator proposed by Elsas and Florysiak (2011) and Elsas and Florysiak (2013). Unlike the much recommended Blundell and Bond (1998) system generalised method of moments (GMM), the bias-corrected least squares dummy variable (LSDVC) and the long difference estimators, the random effects Tobit/DPF maximum likelihood estimator is unbiased, is consistent in the context of unbalanced dynamic panel data with a fractional dependent variable, and also accounts for firm-fixed effects. Leverage ratios are fractional in nature; they occur between 0 and 1 . This makes the random effects Tobit maximum 
likelihood estimator the most suitable estimator for use in this study. The estimator was implemented in Stata using the xttobit command with censors specified as 0 (minimum) and 1 (maximum).

\section{RESULTS}

The test results consist of summary statistics and empirical results.

\subsection{Summary Statistics}

The summary statistics of the sample are presented in Table 1 below.

Table 1. Summary Statistics 2000-2012

\begin{tabular}{l|c|c|c|c|c|c|c|c}
\hline \multicolumn{1}{c|}{ Variable } & No. Obs. & Mean & Median & Std. Dev. & Min. & Max. & Skewness & Kurtosis \\
\hline MDR & 261 & 0.3784 & 0.2373 & 0.3582 & 0.0000 & 1.0000 & 0.4278 & 1.5309 \\
\hline BDR & 261 & 0.3193 & 0.1597 & 0.3314 & 0.0000 & 1.0000 & 0.5673 & 1.6935 \\
\hline Profitability & 290 & 0.0836 & 0.0648 & 0.0718 & 0.0024 & 0.2229 & 0.6631 & 2.2715 \\
\hline Size & 290 & 16.1284 & 16.2821 & 3.1214 & 11.0970 & 20.2769 & -0.1651 & 1.7625 \\
\hline Tangibility & 290 & 0.0347 & 0.0174 & 0.0375 & 0.0033 & 0.1220 & 1.3940 & 3.6242 \\
\hline MTB & 290 & 0.6395 & 0.4233 & 0.5273 & 0.1226 & 1.6907 & 0.2781 & 2.4378 \\
\hline $\boldsymbol{E F W} \boldsymbol{A M} \boldsymbol{B}_{\boldsymbol{t}}^{\boldsymbol{B}}$ & 290 & 0.0436 & 0.0068 & 0.0673 & 0.0000 & 0.2034 & 1.5279 & 3.8998 \\
\hline $\boldsymbol{E} \boldsymbol{E W} \boldsymbol{A M} \boldsymbol{B}_{\boldsymbol{t}}$ & 280 & 0.0533 & 0.0010 & 0.0807 & 0.0000 & 0.2311 & 1.3085 & 3.1605 \\
\hline $\boldsymbol{D W A M B}_{\boldsymbol{t}}$ & 290 & 0.1050 & 0.0013 & 0.1827 & 0.0000 & 0.5510 & 1.7134 & 4.3817 \\
\hline $\boldsymbol{E F W A M B} \boldsymbol{B}_{\boldsymbol{t}}^{\boldsymbol{D}}$ & 289 & 0.0665 & 0.0155 & 0.0948 & 0.0000 & 0.2863 & 1.3832 & 3.5435 \\
\hline
\end{tabular}

The sample consists of 29 JSE-Listed financial services firms with complete data for eight or more consecutive years during 2000 to 2012. The unbalanced panel was constructed from data drawn from standardised annual financial statements of these firms which were obtained from the McGregorBFA database. The total number of observations for the period is 1,839 . To eliminate outlier observations and the most extremely misrecorded data, all variables were winsorised at the 1st and 99th percentiles. Following Baker and Wurgler (2002:12), EFWAMB $B_{t}^{B W}$, $E E W A M B_{t}, D W A M B_{t}$, and $E F W A M B_{t}^{B D}$ values greater than 10 were dropped and negative $E F W A M B_{t}^{B W}$, $E E W A M B_{t}, D W A M B_{t}$, and $E F W A M B_{t}^{B D}$ values were reset to zero.

Market-to-debt ratio (MDR): the total interest-bearing debt (short-term plus long-term) scaled up by the sum of the total debt and the firm market capitalisation.

Book-to-debt ratio (BDR): the total interest-bearing debt (short-term plus long-term) scaled up by the total assets.

Firm profitability (Profitability): earnings before interest, tax, depreciation and amortisation (EBITDA) as a fraction of total assets $(\boldsymbol{T} A)$.

Firm size (Size): the natural logarithm of total assets.

Asset tangibility (Tangibility): the fixed assets scaled up by the total assets.

Un-weighted market-to-book ratio (MTB): the sum of the market value of equity, book value of preference shares and the book value of total debt less deferred taxes; this is scaled up by the total assets.

Weighted market-to-book ratio: are the market timing measures which are defined as follows:

$$
\begin{aligned}
& E F W A M B_{t}^{B W} \equiv \sum_{s=1}^{t-1} \frac{e_{S}+l t d_{s}}{\sum_{r=1}^{t-1} e_{r}+l t d_{r}} \times M B_{s} ; \quad E E W A M B_{t} \equiv \frac{1}{\overline{M B}} \sum_{s=1}^{t-1} \frac{e_{s}}{\sum_{r=1}^{t-1} e_{r}} \times M B_{s} ; \\
& D W A M B_{t} \equiv \frac{1}{\overline{M B}} \sum_{s=1}^{t-1} \frac{l t d_{s}}{\sum_{r=1}^{t-1} l t d_{r}} \times M B_{s} \text { and } E F W A M B_{t}^{B D} \equiv \frac{1}{\overline{M B}} \sum_{s=1}^{t-1} \frac{e_{S}+l t d_{s}}{\sum_{r=1}^{t-1} e_{r}+l t d_{r}} \times M B_{S}
\end{aligned}
$$


Where $e$ and ltd denote net equity and long-term debt issuances respectively; MTB is the un-weighted market-tobook ratio, suffice $s$ represents a specific year issuances and suffice $r$ represents issuances for the total period. Equity and debt issuances are respectively defined as a change (increase) in the book value of share capital and change (increase) in the book value of debt.

With mean MDR and BDR ratios of 0.3784 and 0.3193 respectively, the financial services firms have higher leverage than their non-financial counterparts listed on the JSE. According to Moyo (2014), the JSE-listed nonfinancial firms have a mean a MDR ratio of 0.1716 and a BDR ratio 0.1909. On average, the JSE-listed financial services firms are less profitable, hold less tangible assets and have a lower growth rate when compared to the JSElisted non-financial firms. The non-financial firms have an average profitability, asset tangibility and growth rate of $0.2000,0.3240$ and 1.3374 respectively. The mean size of the financial services firms is 16.1284 which is higher than 14.3066 of non-financial firms. This means that on average the financial services firms are larger than nonfinancial firms. In summary, the JSE-listed financial services firms use more debt than non-financial firms. The firms are also larger, less profitable, have lower growth rates and hold less tangible assets when compared to nonfinancial firms.

\subsection{Empirical Results}

The results for model 1 are contained in Table 2 . The MDR ratio is positively correlated to the external financeweighted average market-to-book ratio $\left(E F W A M B_{t}^{B D}\right)$. The $\mathrm{BDR}$ ratio is however negatively correlated to $E F W A M B_{t}^{B D}$. The correlations are however insignificant in both cases thus rejecting the market timing hypothesis. The results validate the dynamic trade-off theory. Moyo (2014) found similar results for JSE-listed non-financial firms. This means that the JSE-listed firms do not time the market when making equity issuance decisions.

\subsection{Leverage and Firm-Specific Factors}

Profitability: In both the MDR and the BDR regressions, profitability is positively correlated to leverage. The correlation is however insignificant making profitability a weak predictor of firm leverage. The results mean leverage increases with firm profitability. This result is inconsistent with the pecking order theory but consistent with the trade-off theory.

Size: Size is positively related to both the MDR and the BDR. It has a higher power to explain the MDR ratio than the BDR ratio. In the financial services firms, leverage increases with firms. Large firms use more debt while smaller firms rely on equity finance.

Tangibility: The results confirm a positive correlation between tangibility and MDR and BDR. In some cases it is a significant predictor of the MDR. The leverage of the financial services firms increase with the firm's stock of tangible assets. 
Table 2. The Effects of Historical Weighted Market-to-Book in MDR and BDR Capital Structure Regressions

\begin{tabular}{|c|c|c|c|c|c|}
\hline & \multicolumn{5}{|c|}{ Variables } \\
\hline & Profitability & Size & Tangibility & MTB & $E F W A M B_{t}^{B D}$ \\
\hline \multicolumn{6}{|c|}{ Market Leverage (MDR) } \\
\hline $2003-2007$ & $\begin{array}{l}0.2900 \\
(0.92) \\
\end{array}$ & $\begin{array}{l}0.0263 * * \\
(3.26)\end{array}$ & $\begin{array}{l}-0.0640 \\
(-0.10) \\
\end{array}$ & $\begin{array}{c}0.0408 \\
(0.84) \\
\end{array}$ & $\begin{array}{l}0.1129 \\
(0.80)\end{array}$ \\
\hline 2004-2008 & $\begin{array}{l}0.4308 \\
(1.49)\end{array}$ & $\begin{array}{l}0.0316^{* * *} \\
(3.89)\end{array}$ & $\begin{array}{l}0.5520 \\
(0.80)\end{array}$ & $\begin{array}{c}0.0469 \\
(1.05)\end{array}$ & $\begin{array}{l}0.1646 \\
(1.09)\end{array}$ \\
\hline $2005-2009$ & $\begin{array}{l}0.3032 \\
(1.48)\end{array}$ & $\begin{array}{l}0.0833 * * * \\
(8.98)\end{array}$ & $\begin{array}{l}2.6758 * * * \\
(3.86)\end{array}$ & $\begin{array}{l}0.1192 * * \\
(2.98)\end{array}$ & $\begin{array}{r}-0.0240 \\
(-0.19)\end{array}$ \\
\hline $2006-2010$ & $\begin{array}{c}0.2717 \\
(1.15) \\
\end{array}$ & $\begin{array}{l}0.0224 * * \\
(3.01) \\
\end{array}$ & $\begin{array}{l}1.0745^{*} \\
(2.05) \\
\end{array}$ & $\begin{array}{r}0.0561 \\
(1.43) \\
\end{array}$ & $\begin{array}{l}0.1900 \\
(0.99)\end{array}$ \\
\hline $2007-2011$ & $\begin{array}{l}0.2676 \\
(1.01)\end{array}$ & $\begin{array}{l}0.0054 \\
(0.75)\end{array}$ & $\begin{array}{l}0.5024 \\
(1.09)\end{array}$ & $\begin{array}{c}0.0458 \\
(1.17)\end{array}$ & $\begin{array}{l}0.2062 \\
(0.99)\end{array}$ \\
\hline $2008-2012$ & $\begin{array}{l}0.0296 \\
(0.11)\end{array}$ & $\begin{array}{l}0.0133 * \\
(1.99)\end{array}$ & $\begin{array}{l}1.1681 * * \\
(3.02)\end{array}$ & $\begin{array}{l}0.0938^{*} \\
(2.20)\end{array}$ & $\begin{array}{r}-0.0452 \\
(-0.19)\end{array}$ \\
\hline Full Sample & $\begin{array}{l}-0.0009 \\
(-0.00)\end{array}$ & $\begin{array}{l}0.0704 * * * \\
(5.55)\end{array}$ & $\begin{array}{l}1.6520 * * \\
(2.65)\end{array}$ & $\begin{array}{l}0.1517 * * * \\
(3.36)\end{array}$ & $\begin{array}{l}0.0430 \\
(0.37)\end{array}$ \\
\hline \multicolumn{6}{|c|}{ Book Leverage ( BDR ) } \\
\hline $2003-2007$ & $\begin{array}{l}0.4962 * \\
(2.16)\end{array}$ & $\begin{array}{c}0.0068 \\
(1.14)\end{array}$ & $\begin{array}{l}-0.5798 \\
(-1.21) \\
\end{array}$ & $\begin{array}{l}-0.0262 \\
(-1.21) \\
\end{array}$ & $\begin{array}{c}0.0308 \\
(0.30) \\
\end{array}$ \\
\hline 2004-2008 & $\begin{array}{c}0.2128 \\
(0.84) \\
\end{array}$ & $\begin{array}{c}0.1364 \\
(1.86) \\
\end{array}$ & $\begin{array}{c}0.3219 \\
(0.53) \\
\end{array}$ & $\begin{array}{l}0.0244 \\
(0.63) \\
\end{array}$ & $\begin{array}{l}-0.0274 \\
(-0.21) \\
\end{array}$ \\
\hline $2005-2009$ & $\begin{array}{l}0.5436^{*} \\
(2.23)\end{array}$ & $\begin{array}{l}0.0173 * \\
(2.24)\end{array}$ & $\begin{array}{l}0.3050 \\
(0.50)\end{array}$ & $\begin{array}{l}0.0187 \\
(0.46)\end{array}$ & $\begin{array}{l}-0.0059 \\
(-0.04)\end{array}$ \\
\hline $2006-2010$ & $\begin{array}{c}0.2528 \\
(0.90)\end{array}$ & $\begin{array}{l}0.0186^{*} \\
(2.13)\end{array}$ & $\begin{array}{c}0.9661 \\
(1.55)\end{array}$ & $\begin{array}{l}0.0642 \\
(1.36)\end{array}$ & $\begin{array}{l}-0.0297 \\
(-0.13)\end{array}$ \\
\hline $2007-2011$ & $\begin{array}{l}0.1486 \\
(0.63)\end{array}$ & $\begin{array}{l}0.0405^{* * *} \\
(5.78)\end{array}$ & $\begin{array}{l}1.0425^{*} \\
(2.55)\end{array}$ & $\begin{array}{l}-0.0265 \\
(-0.76)\end{array}$ & $\begin{array}{l}-0.1514 \\
(-0.87)\end{array}$ \\
\hline $2008-2012$ & $\begin{array}{l}0.0840 \\
(0.23)\end{array}$ & $\begin{array}{l}0.0304 * * * \\
(3.53)\end{array}$ & $\begin{array}{l}1.6527^{* *} \\
(3.24)\end{array}$ & $\begin{array}{l}0.1434^{*} \\
(2.50)\end{array}$ & $\begin{array}{l}-0.4490 \\
(-1.41)\end{array}$ \\
\hline Full Sample & $\begin{array}{l}-0.2907 \\
(-1.67)\end{array}$ & $\begin{array}{l}0.0487 * * * \\
(7.05)\end{array}$ & $\begin{array}{l}-0.2913 \\
(-0.94)\end{array}$ & $\begin{array}{c}0.0464 \\
(1.67)\end{array}$ & $\begin{array}{l}0.1057 \\
(1.03)\end{array}$ \\
\hline
\end{tabular}


(Table 2 Continued)

\begin{tabular}{|c|c|c|c|c|c|c|}
\hline & \multicolumn{3}{|c|}{$\begin{array}{c}\text { Speed of Adjustment } \\
\end{array}$} & \multicolumn{3}{|c|}{ Fit Statistics } \\
\hline & $\begin{array}{c}\text { Lev_t-1 } \\
\text { Coefficient }\end{array}$ & SOA $(\lambda)$ & $\begin{array}{c}\text { Half-life } \\
\text { (years) }\end{array}$ & Obs & Wald Chi2 & Prob $>$ Chi2 \\
\hline \multicolumn{7}{|c|}{ Market Leverage (MDR) } \\
\hline $2003-2007$ & $\begin{array}{l}0.7776^{* * *} \\
(11.63)\end{array}$ & $22.24 \%$ & 2.76 & 144 & 244.31 & 0.0000 \\
\hline 2004-2008 & $\begin{array}{l}0.7746^{* * *} \\
(12.07)\end{array}$ & $22.54 \%$ & 2.71 & 145 & 287.00 & 0.0000 \\
\hline $2005-2009$ & $\begin{array}{l}0.2818 * * * \\
(3.73)\end{array}$ & $71.82 \%$ & 0.55 & 145 & 310.34 & 0.00000 \\
\hline $2006-2010$ & $\begin{array}{l}0.8783 * * * \\
(16.05)\end{array}$ & $12.17 \%$ & 5.34 & 145 & 483.03 & 0.0000 \\
\hline $2007-2011$ & $\begin{array}{l}0.9675^{* * *} \\
(18.96)\end{array}$ & $3.25 \%$ & 20.98 & 145 & 578.40 & 0.000 \\
\hline $2008-2012$ & $\begin{array}{l}0.9651^{* * *} \\
(20.83)\end{array}$ & $3.49 \%$ & 19.51 & 116 & 681.08 & 0.0000 \\
\hline Full Sample & $\begin{array}{c}0.4320 * * * \\
(6.44)\end{array}$ & $56.80 \%$ & 0.83 & 260 & 189.28 & 0.0000 \\
\hline \multicolumn{7}{|c|}{ Book Leverage ( BDR ) } \\
\hline $2003-2007$ & $\begin{array}{l}0.8866 * * * \\
(16.80)\end{array}$ & $11.34 \%$ & 5.76 & 144 & 403.44 & 0.0000 \\
\hline 2004-2008 & $\begin{array}{l}0.8573 * * * \\
(14.67) \\
\end{array}$ & $14.27 \%$ & 4.50 & 145 & 310.71 & 0.0000 \\
\hline $2005-2009$ & $\begin{array}{l}0.8300 * * * \\
(14.62)\end{array}$ & $17.00 \%$ & 3.72 & 145 & 315.15 & 0.0000 \\
\hline $2006-2010$ & $\begin{array}{l}0.8523 * * * \\
(14.20)\end{array}$ & $14.77 \%$ & 4.34 & 145 & 284.82 & 0.0000 \\
\hline $2007-2011$ & $\begin{array}{l}-0.0357 \\
(-0.47)\end{array}$ & $103.57 \%$ & - & 145 & 67.21 & 0.0000 \\
\hline $2008-2012$ & $\begin{array}{l}0.8434 * * * \\
(15.38)\end{array}$ & $15.66 \%$ & 4.07 & 116 & 347.66 & 0.0000 \\
\hline Full Sample & $\begin{array}{l}0.2869 * * * \\
(4.29)\end{array}$ & $71.31 \%$ & 0.56 & 260 & 259.45 & 0.0000 \\
\hline
\end{tabular}

Firm growth rate: The growth rate is positively correlated to both MDR and BDR. The correlations are however insignificant. This result means that high growth financial services firms rely on debt finance whilst low growth firms use more equity.

Regression results for the partial adjustment model:

$$
L e v_{i, t+1}=\alpha+(1-\lambda) L e v_{i, t}+\lambda \beta_{1} X_{t}+\lambda \beta_{2} E F W A M B_{t}^{B D}+c_{i, t}+\varepsilon_{i, t+1}
$$

Where $\lambda$ is the SOA towards the target leverage, $c_{i, T}$ is the time-invariant unobserved variable (firm fixed effect) and $\varepsilon_{i, T+1}$ is an error term. The variables determining the firm's long-run target leverage and the SOA are: profitability, size, tangibility and un-weighted market-to-book, and these are defined in Table $1 . E F W A M B_{t}^{B D}$ is the Bruinshoofd and De Haan (2012) market timing measure which is also defined in Table 1. T-statistics are reported in parentheses. The markings $* * *, * *$ and $*$ on coefficient estimates denote significant differences from zero at the levels of $1 \%, 5 \%$, and $10 \%$ respectively. The implied half-life is calculated as: half - life $=$ $\log (0.5) / \log (1-\lambda)$. Model specifications are shown under fit statistics.

The correlation results on profitability, firm size and asset tangibility are all consistent with the predictions of the trade-off theory. The positive correlation between leverage and firm growth rate however rejects the trade-off hypothesis. According Barclay and Smith (2005), profitable firms tend to be large, mature, have limited growth options and have a high stock of assets in place (tangibles). Jensen (1986) contends that these firms have a higher propensity to generate excess free cash flows which can increase the firm's agency costs of overinvestment. The 
firms also face increased tax bills which derive from their high profits and low non-debt tax shields in the form of capital allowances. On the other hand, the high profitability coupled with high stocks of assets in place increases the firm's credit ratings, thus lowering the firm's cost of borrowing (Kisgen, 2007). The trade-off theory contends that using more debt in large, mature and profitable firms effectively reduces their taxes and agency costs of overinvestment thus increasing shareholder value (Harvey, Lins \& Roper (2004); Jensen (1986:323); and Stulz (1990) and Bessler et al (2011). The increased debt interest tax shield adds to the value of the firm. Thus large, mature and profitable have strong incentive to exploit the tax advantage of the debt interest tax shield (Dang, 2013). In summary, the JSE-listed financial services firms seem to follow the trade-off theory in raising capital. The correlation son all the four factors reject the pecking order hypothesis.

\subsection{Target SOA}

In all cases, the firms have a positive and significant SOA towards the target leverage. The speed increases with time and sample size indicating that the full sample SOA is the least biased. The true SOA for the sample is $56.80 \%$ (half-life of 0.83 years) for the MDR and $71.31 \%$ (half-life of 0.56 years) for the BDR. This means that, in the case of the MDR, $56.80 \%$ of the target deviation spread is covered in one year and it takes 0.83 years to cover $50 \%$ of the target deviation spread. These results validate the dynamic trade-off theory and both reject the market timing and pecking order theories. The target SOA for the financial services firms is however faster than that of the JSE-listed non-financial firms. Using the same random effects Tobit estimator, Moyo et al (2013) documented a target SOA of 42.44\% (MDR) and 57.64\% (BDR) for JSE-listed manufacturing, mining and retail firms. Ramjee and Gwatidzo (2012) found that the SOA towards the target leverage was $65.50 \%$ (on total debt ratio) for JSE-listed non-financial services firms. The higher SOA implies that the financial firms are more active in adjusting their capital structures towards the optimal levels. Interestingly, the SOA results are also consistent with the buffer capital and optimal bank capital structure hypotheses which, according to Berger et al (2008), posits that banks actively reliance their capital structures to the optimal. 
Table 3. Dynamic Capital Structure Regressions Using Only Firm-Specific Variables

\begin{tabular}{|c|c|c|c|c|}
\hline & \multicolumn{4}{|c|}{ Variables } \\
\hline & Profitability & Size & Tangibility & MTB \\
\hline \multicolumn{5}{|c|}{ Market Leverage (MDR) } \\
\hline $2003-2007$ & $\begin{array}{l}0.2635 \\
(0.84)\end{array}$ & $\begin{array}{l}0.0273 * * * \\
(3.44)\end{array}$ & $\begin{array}{c}0.0318 \\
(0.05)\end{array}$ & $\begin{array}{c}0.0482 \\
(1.02)\end{array}$ \\
\hline 2004-2008 & $\begin{array}{l}0.3564 \\
(1.07)\end{array}$ & $\begin{array}{l}0.0612 * * \\
(3.20)\end{array}$ & $\begin{array}{l}0.8858 \\
(0.86)\end{array}$ & $\begin{array}{c}0.1093 \\
(1.89) \\
\end{array}$ \\
\hline $2005-2009$ & $\begin{array}{l}0.3032 \\
(1.48)\end{array}$ & $\begin{array}{l}0.0831 * * * \\
(9.00)\end{array}$ & $\begin{array}{l}2.6519 * * * \\
(3.88)\end{array}$ & $\begin{array}{l}0.1183 * * \\
(2.99)\end{array}$ \\
\hline $2006-2010$ & $\begin{array}{c}0.2874 \\
(1.22) \\
\end{array}$ & $\begin{array}{l}0.0231 * * \\
(3.10)\end{array}$ & $\begin{array}{l}1.1695^{*} \\
(2.26) \\
\end{array}$ & $\begin{array}{c}0.0640 \\
(1.66) \\
\end{array}$ \\
\hline $2007-2011$ & $\begin{array}{c}0.2838 \\
(1.07)\end{array}$ & $\begin{array}{c}0.0066 \\
(0.91)\end{array}$ & $\begin{array}{l}0.5809 \\
(1.28)\end{array}$ & $\begin{array}{c}0.0556 \\
(1.45) \\
\end{array}$ \\
\hline $2008-2012$ & $\begin{array}{c}0.0291 \\
(0.11) \\
\end{array}$ & $\begin{array}{c}0.0131^{*} \\
(1.99)\end{array}$ & $\begin{array}{l}1.1537 * * \\
(3.05)\end{array}$ & $\begin{array}{c}0.0914 * \\
(2.25)\end{array}$ \\
\hline Full Sample & $\begin{array}{l}-0.0036 \\
(-0.01))\end{array}$ & $\begin{array}{l}0.0700 * * * \\
(5.29)\end{array}$ & $\begin{array}{c}1.6346^{*} \\
(2.56)\end{array}$ & $\begin{array}{l}0.1523 * * * \\
(3.36)\end{array}$ \\
\hline \multicolumn{5}{|c|}{ Book Leverage ( BDR ) } \\
\hline $2003-2007$ & $\begin{array}{c}0.4921^{*} \\
(2.17)\end{array}$ & $\begin{array}{c}0.0070 \\
(1.18)\end{array}$ & $\begin{array}{c}-0.5566 \\
(-1.19)\end{array}$ & $\begin{array}{c}-0.0251 \\
(-0.75)\end{array}$ \\
\hline 2004-2008 & $\begin{array}{c}0.2183 \\
(0.86) \\
\end{array}$ & $\begin{array}{c}0.0135 \\
(1.85) \\
\end{array}$ & $\begin{array}{c}0.3073 \\
(0.51) \\
\end{array}$ & $\begin{array}{c}0.0230 \\
(0.60) \\
\end{array}$ \\
\hline $2005-2009$ & $\begin{array}{c}0.5437^{*} \\
(2.23) \\
\end{array}$ & $\begin{array}{c}0.0173^{*} \\
(2.24) \\
\end{array}$ & $\begin{array}{l}0.3015 \\
(0.50) \\
\end{array}$ & $\begin{array}{l}0.0185 \\
(0.46)\end{array}$ \\
\hline $2006-2010$ & $\begin{array}{c}0.2505 \\
(0.90) \\
\end{array}$ & $\begin{array}{c}0.0184^{*} \\
(2.13)\end{array}$ & $\begin{array}{c}0.9514 \\
(1.55) \\
\end{array}$ & $\begin{array}{c}0.0630 \\
(1.37) \\
\end{array}$ \\
\hline $2007-2011$ & $\begin{array}{c}0.1596 \\
(0.58)\end{array}$ & $\begin{array}{l}0.0387 * * * \\
(4.61)\end{array}$ & $\begin{array}{l}0.9553 * \\
(2.29)\end{array}$ & $\begin{array}{c}-0.0318 \\
(-0.92)\end{array}$ \\
\hline $2008-2012$ & $\begin{array}{c}0.0804 \\
(0.22) \\
\end{array}$ & $\begin{array}{l}0.0282 * * * \\
(3.30)\end{array}$ & $\begin{array}{l}1.5157^{* *} \\
(3.01)\end{array}$ & $\begin{array}{l}0.1226^{*} \\
(2.19)\end{array}$ \\
\hline Full Sample & $\begin{array}{l}0.3065 \\
(1.78)\end{array}$ & $\begin{array}{l}0.0293 * * * \\
(5.55)\end{array}$ & $\begin{array}{c}0.2768 \\
(0.86)\end{array}$ & $\begin{array}{l}0.0028 \\
(0.10)\end{array}$ \\
\hline
\end{tabular}


(Table 3 Continued)

\begin{tabular}{|c|c|c|c|c|c|c|}
\hline 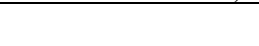 & \multicolumn{3}{|c|}{$\begin{array}{l}\text { Speed of Adjustment } \\
\end{array}$} & \multicolumn{3}{|c|}{ Fit Statistics } \\
\hline & $\begin{array}{c}\text { Lev_t-1 } \\
\text { Coefficient }\end{array}$ & SOA $(\lambda)$ & $\begin{array}{c}\begin{array}{c}\text { Half-life } \\
\text { (years) }\end{array} \\
\end{array}$ & Obs & Wald Chi2 & $\begin{array}{c}\text { Prob> } \\
\text { Chi2 } \\
\end{array}$ \\
\hline \multicolumn{7}{|c|}{ Market Leverage (MDR) } \\
\hline $2003-2007$ & $\begin{array}{l}0.7788^{* * *} \\
(11.74)\end{array}$ & $22.12 \%$ & 2.77 & 145 & 249.42 & 0.0000 \\
\hline 2004-2008 & $\begin{array}{l}0.4607^{* *} \\
(2.85)\end{array}$ & $53.93 \%$ & 0.89 & 145 & 74.21 & 0.0000 \\
\hline $2005-2009$ & $\begin{array}{l}0.2839 * * * \\
(3.79)\end{array}$ & $71.61 \%$ & 0.55 & 145 & 308.21 & 0.00000 \\
\hline $2006-2010$ & $\begin{array}{l}0.8802 * * * \\
(16.06)\end{array}$ & $11.98 \%$ & 5.43 & 145 & 480.27 & 0.0000 \\
\hline $2007-2011$ & $\begin{array}{l}0.9709 * * * \\
(19.00)\end{array}$ & $2.91 \%$ & 23.47 & 145 & 573.92 & 0.0000 \\
\hline $2008-2012$ & $\begin{array}{c}0.9643 * * * \\
(20.90) \\
\end{array}$ & $3.57 \%$ & 19.07 & 116 & 681.04 & 0.0000 \\
\hline Full Sample & $\begin{array}{l}0.4320 * * * \\
(6.40)\end{array}$ & $56.80 \%$ & 0.83 & 261 & 169.74 & 0.0000 \\
\hline \multicolumn{7}{|c|}{ Book Leverage ( BDR ) } \\
\hline 2003-2007 & $\begin{array}{l}0.8846^{* * *} \\
(16.92)\end{array}$ & $11.54 \%$ & 5.65 & 145 & 411.97 & 0.0000 \\
\hline 2004-2008 & $\begin{array}{l}0.8573 * * * \\
(14.66)\end{array}$ & $14.27 \%$ & 4.50 & 145 & 310.25 & 0.0000 \\
\hline $2005-2009$ & $\begin{array}{l}0.8300^{* * * *} \\
(14.63)\end{array}$ & $17.00 \%$ & 3.72 & 145 & 315.08 & 0.0000 \\
\hline $2006-2010$ & $\begin{array}{l}0.8524 * * * \\
(14.20)\end{array}$ & $14.76 \%$ & 4.34 & 145 & 284.24 & 0.0000 \\
\hline $2007-2011$ & $\begin{array}{l}-0.0264 \\
(-0.33)\end{array}$ & $106.24 \%$ & - & 145 & 49.23 & 0.0000 \\
\hline $2008-2012$ & $\begin{array}{l}0.8340 * * * \\
(15.18)\end{array}$ & $16.60 \%$ & 3.82 & 116 & 340.49 & 0.0000 \\
\hline Full Sample & $\begin{array}{l}0.5122 * * * \\
(9.69)\end{array}$ & $48.78 \%$ & 1.04 & 261 & 345.82 & 0.0000 \\
\hline
\end{tabular}

\subsection{Capital Structure Regressions Results}

The results of the variables follow those of test 1 described above. Profitability, firm size, asset tangibility and growth rate are all positively correlated to both the MDR and the BDR. Firm size is a significant determinant of leverage for the full sample. The SOA also follows the same pattern exhibited in test 1.The true SOA for the sample is $56.80 \%$ (half-life of 0.83 years) for the MDR and $48.78 \%$ (half-life of 1.04 years) for the BDR. The market timing measure has a negligible impact on MDR regressions but its exclusion reduces the BDR SOA.

Regression results for the partial adjustment model:

$$
L e v_{i, t+1}=\alpha+(1-\lambda) L e v_{i, t}+\lambda \beta_{1} X_{t}+c_{i, t}+\varepsilon_{i, t+1}
$$

Where $\lambda$ is the SOA towards the target leverage, $c_{i, T}$ is the time-invariant unobserved variable (firm fixed effect) and $\varepsilon_{i, T+1}$ is an error term. The variables determining the firm's long-run target leverage and the SOA are: profitability, size, tangibility and un-weighted market-to-book, and these are defined in Table 1. T-statistics are reported in parentheses. The markings $* * *, * *$ and $*$ on coefficient estimates denote significant differences from zero at the levels of $1 \%, 5 \%$, and $10 \%$ respectively. The implied half-life is calculated as: half -life $=$ $\log (0.5) / \log (1-\lambda)$. Model specifications are shown under fit statistics. 


\subsection{Robustness Test}

The study used two further tests to check for the robustness of the rejection of the market timing theory. The first robustness test involved using the market timing measure suggested by Baker and Wurgler (2002), the $E F W A M B_{t}^{B W}$. Following Bruinshoofd and De Haan (2012), this measure was computed using only long-term debt. Thus regression model 1 was modified to:

$$
\operatorname{Lev}_{i, t+1}=\alpha+(1-\lambda) \operatorname{Lev}_{i, t}+\lambda\left(\boldsymbol{X}_{i, t} \gamma_{1}\right)+\lambda \gamma_{2} E F W A M B_{t}^{B W}+c_{i, t}+\varepsilon_{i, t+1}
$$

This is regression model 3. To validate the market timing theory, $E F W A M B_{t}^{B W}$ must be significantly correlated to leverage, otherwise the market timing theory is rejected.

The second robustness test was suggested by Bruinshoofd and De Haan (2012) and uses two alternative market timing measures namely the external equity-weighted average market-to-book ratio (EEWAMB) and the long-term debt-weighted average market-to-book ratio (DWAMB), defined as follows:

$$
\begin{aligned}
& E E W A M B_{t}=\frac{1}{\overline{M B}} \sum_{s=1}^{t-1} \frac{e_{s}}{\sum_{r=1}^{t-1} e_{r}} \times M B_{S} \\
& D W A M B_{t}=\frac{1}{\overline{M B}} \sum_{s=1}^{t-1} \frac{t t d_{s}}{\sum_{r=1}^{t-1} l t d_{r}} \times M B_{S}
\end{aligned}
$$

These measures separately test for the market timing hypothesis of both equity and debt issuance decisions. The $D W A M B_{t}$ uses only long-term debt issuance, as this is more likely to represent market timing than short-term debt does. The regression model 1 partial adjustment model is therefore restated as:

$$
\begin{aligned}
& \operatorname{Lev}_{i, t+1}=\alpha+(1-\lambda) L e v_{i, t}+\lambda\left(\boldsymbol{X}_{i, t} \gamma_{1}\right)+\lambda \gamma_{2} E E W A M B_{t}+\lambda \gamma_{3} D W A M B_{t}+c_{i, t}+ \\
& \varepsilon_{i, t+1}
\end{aligned}
$$

This is regression model 4. A significant negative correlation between leverage and EEWAMB confirms the validity of the market timing theory, whilst a positive correlation validates the static trade-off theory. A significant positive correlation between $D W A M B$ and leverage validates the market timing theory. The results of both tests are contained in tables 4 and 5 respectively.

Regression results for the partial adjustment model:

$$
\operatorname{Lev}_{i, t+1}=\alpha+(1-\lambda) \operatorname{Lev}_{i, t}+\lambda \beta_{1} X_{t}+\lambda \beta_{2} E F W A M B_{t}^{B W}+c_{i, t}+\varepsilon_{i, t+1}
$$

Where $\lambda$ is the SOA towards the target leverage, $c_{i, T}$ is the time-invariant unobserved variable (firm fixed effect) and $\varepsilon_{i, T+1}$ is an error term. The variables determining the firm's long-run target leverage and the SOA are: profitability, size, tangibility and un-weighted market-to-book, and these are defined in Table 1. $E F W A M B_{t}^{B W}$ is the modified Baker and Wurgler (2002) market timing measure which is also defined in Table 1. T-statistics are reported in parentheses. The markings $* * *, * *$ and $*$ on coefficient estimates denote significant differences from zero at the levels of $1 \%, 5 \%$, and $10 \%$ respectively. The implied half-life is calculated as: half - life $=\log (0.5) / \log (1-\lambda)$. Model specifications are shown under fit statistics. 
Table 4. Robustness Test: The Impact of the Modified Baker and Wurgler (2002) Market Timing Measure on Capital Structure Regressions

\begin{tabular}{|c|c|c|c|c|c|}
\hline & \multicolumn{5}{|c|}{ Variables } \\
\hline & Profitability & Size & Tangibility & MTB & $E F W A M B_{t}^{B W}$ \\
\hline \multicolumn{6}{|c|}{ Market Leverage (MDR) } \\
\hline $2003-2007$ & $\begin{array}{c}0.2776 \\
(0.89)\end{array}$ & $\begin{array}{l}0.0270^{* * *} \\
(3.41)\end{array}$ & $\begin{array}{c}-0.0297 \\
(-0.05)\end{array}$ & $\begin{array}{l}0.0321 \\
(0.62)\end{array}$ & $\begin{array}{c}0.1897 \\
(0.76)\end{array}$ \\
\hline 2004-2008 & $\begin{array}{l}0.3399 \\
(1.01) \\
\end{array}$ & $\begin{array}{l}0.0611 * * \\
(3.10)\end{array}$ & $\begin{array}{c}0.8523 \\
(0.82)\end{array}$ & $\begin{array}{c}0.1000 \\
1.66)\end{array}$ & $\begin{array}{c}0.1324 \\
(0.65)\end{array}$ \\
\hline $2005-2009$ & $\begin{array}{l}0.1375 \\
(0.61)\end{array}$ & $\begin{array}{l}0.0862 * * * \\
(8.06)\end{array}$ & $\begin{array}{l}1.2100 \\
(1.63)\end{array}$ & $\begin{array}{l}0.1756^{* * * *} \\
(3.54)\end{array}$ & $\begin{array}{l}0.0282 \\
(0.19)\end{array}$ \\
\hline $2006-2010$ & $\begin{array}{c}0.2548 \\
(1.08)\end{array}$ & $\begin{array}{l}0.0231^{* *} \\
(3.13)\end{array}$ & $\begin{array}{l}1.0972 * \\
(2.13)\end{array}$ & $\begin{array}{c}0.0446 \\
(1.10)\end{array}$ & $\begin{array}{l}0.3611 \\
(1.37)\end{array}$ \\
\hline $2007-2011$ & $\begin{array}{l}0.2630 \\
(0.99) \\
\end{array}$ & $\begin{array}{c}0.0064 \\
(0.90) \\
\end{array}$ & $\begin{array}{l}0.5467 \\
(1.20) \\
\end{array}$ & $\begin{array}{c}0.0379 \\
(0.90) \\
\end{array}$ & $\begin{array}{c}0.2486 \\
(1.00) \\
\end{array}$ \\
\hline $2008-2012$ & $\begin{array}{c}0.0400 \\
(0.15) \\
\end{array}$ & $\begin{array}{l}0.0132 \\
(1.75) \\
\end{array}$ & $\begin{array}{l}1.1881 \text { ** } \\
(2.98)\end{array}$ & $\begin{array}{l}0.1079 * \\
(2.27)\end{array}$ & $\begin{array}{c}-0.2655 \\
(-0.82) \\
\end{array}$ \\
\hline Full Sample & $\begin{array}{c}-0.2271 \\
(-0.68)\end{array}$ & $\begin{array}{l}0.0464 * * * \\
(6.76)\end{array}$ & $\begin{array}{l}0.6714 \\
(1.76)\end{array}$ & $\begin{array}{l}0.1562 * * * \\
(3.43)\end{array}$ & $\begin{array}{c}0.1018 \\
(0.54) \\
\end{array}$ \\
\hline \multicolumn{6}{|c|}{ Book Leverage ( BDR ) } \\
\hline $2003-2007$ & $\begin{array}{c}0.5064 * \\
(2.23) \\
\end{array}$ & $\begin{array}{c}0.0068 \\
(1.15)\end{array}$ & $\begin{array}{c}-0.6118 \\
(-1.30) \\
\end{array}$ & $\begin{array}{c}-0.0388 \\
(-1.06) \\
\end{array}$ & $\begin{array}{c}0.1649 \\
(0.92) \\
\end{array}$ \\
\hline $2004-2008$ & $\begin{array}{c}0.2174 \\
(0.86) \\
\end{array}$ & $\begin{array}{c}0.0135 \\
(1.84) \\
\end{array}$ & $\begin{array}{c}0.3088 \\
(0.51) \\
\end{array}$ & $\begin{array}{c}0.0238 \\
(0.58) \\
\end{array}$ & $\begin{array}{c}-0.0098 \\
(-0.05) \\
\end{array}$ \\
\hline $2005-2009$ & $\begin{array}{c}0.5426^{*} \\
(2.22) \\
\end{array}$ & $\begin{array}{c}0.0172 * \\
(2.22) \\
\end{array}$ & $\begin{array}{c}0.3106 \\
(0.51) \\
\end{array}$ & $\begin{array}{c}0.0208 \\
(0.49) \\
\end{array}$ & $\begin{array}{c}-0.0286 \\
(-0.16) \\
\end{array}$ \\
\hline $2006-2010$ & $\begin{array}{c}0.2553 \\
(0.91) \\
\end{array}$ & $\begin{array}{c}0.0184^{*} \\
(2.13)\end{array}$ & $\begin{array}{c}0.9623 \\
(1.56) \\
\end{array}$ & $\begin{array}{c}0.0659 \\
(1.35) \\
\end{array}$ & $\begin{array}{c}-0.0560 \\
(-0.18)\end{array}$ \\
\hline $2007-2011$ & $\begin{array}{c}0.1874 \\
(0.68) \\
\end{array}$ & $\begin{array}{l}0.0382 * * * \\
(4.56)\end{array}$ & $\begin{array}{l}0.9718^{*} \\
(2.30)\end{array}$ & $\begin{array}{c}-0.02336 \\
(-0.65)\end{array}$ & $\begin{array}{c}-0.1395 \\
(-0.24) \\
\end{array}$ \\
\hline $2008-2012$ & $\begin{array}{l}0.1153 \\
(0.32)\end{array}$ & $\begin{array}{l}0.0282 * * * \\
(3.37)\end{array}$ & $\begin{array}{l}1.6173 * * \\
(3.26)\end{array}$ & $\begin{array}{l}0.1724 * * \\
(2.90)\end{array}$ & $\begin{array}{c}-0.9294^{*} \\
(-2.23) \\
\end{array}$ \\
\hline Full Sample & $\begin{array}{c}0.0093 \\
(0.05) \\
\end{array}$ & $\begin{array}{l}0.0459 * * * \\
(6.34)\end{array}$ & $\begin{array}{c}0.4725 \\
(1.21) \\
\end{array}$ & $\begin{array}{l}0.0978 * * \\
(2.86)\end{array}$ & $\begin{array}{c}0.0104 \\
(0.07) \\
\end{array}$ \\
\hline
\end{tabular}


(Table 4 Continued)

\begin{tabular}{|c|c|c|c|c|c|c|}
\hline & \multicolumn{3}{|c|}{$\begin{array}{l}\text { Speed of Adjustment } \\
\end{array}$} & \multicolumn{3}{|c|}{ Fit Statistics } \\
\hline & $\begin{array}{c}\text { Lev_t+1 } \\
\text { Coefficient }\end{array}$ & $\operatorname{SOA}(\lambda)$ & $\begin{array}{c}\text { Half-life } \\
\text { (years) }\end{array}$ & Obs & Wald Chi2 & Prob $>$ Chi2 \\
\hline \multicolumn{7}{|c|}{ Market Leverage (MDR) } \\
\hline 2003-2007 & $\begin{array}{l}0.7765^{* * *} \\
(11.71)\end{array}$ & $22.35 \%$ & 2.74 & 145 & 250.64 & 0.0000 \\
\hline 2004-2008 & $\begin{array}{l}0.4606^{* * *} \\
(2.76)\end{array}$ & $53.94 \%$ & 0.89 & 145 & 74.66 & 0.0000 \\
\hline $2005-2009$ & $\begin{array}{l}0.3017 * * * \\
(3.98)\end{array}$ & $69.83 \%$ & 0.58 & 145 & 338.68 & 0.0000 \\
\hline $2006-2010$ & $\begin{array}{l}0.8781 * * * \\
(16.11)\end{array}$ & $12.19 \%$ & 5.33 & 145 & 487.04 & 0.0000 \\
\hline $2007-2011$ & $\begin{array}{l}0.9658^{* * * *} \\
(18.89)\end{array}$ & $3.42 \%$ & 19.92 & 145 & 579.16 & 0.0000 \\
\hline $2008-2012$ & $\begin{array}{l}0.9698 * * * \\
(17.24)\end{array}$ & $3.02 \%$ & 22.60 & 116 & 572.71 & 0.0000 \\
\hline Full Sample & $\begin{array}{l}0.3790^{* * *} \\
(4.21)\end{array}$ & $62.10 \%$ & 0.71 & 261 & 159.21 & 0.0000 \\
\hline \multicolumn{7}{|c|}{ Book Leverage ( BDR ) } \\
\hline $2003-2007$ & $\begin{array}{l}0.8827 * * * \\
(9.72)\end{array}$ & $11.73 \%$ & 5.56 & 145 & 414.18 & 0.0000 \\
\hline 2004-2008 & $\begin{array}{l}0.8574 * * * \\
(14.66)\end{array}$ & $14.26 \%$ & 4.51 & 145 & 310.33 & 0.0000 \\
\hline $2005-2009$ & $\begin{array}{l}0.8305^{* * *} \\
(14.62)\end{array}$ & $16.95 \%$ & 3.73 & 145 & 315.33 & 0.0000 \\
\hline $2006-2010$ & $\begin{array}{l}0.8529 * * * \\
(14.19)\end{array}$ & $14.71 \%$ & 4.36 & 145 & 284.44 & 0.0000 \\
\hline $2007-2011$ & $\begin{array}{l}-0.1974 \\
(-0.24)\end{array}$ & $119.74 \%$ & - & 145 & 47.38 & 0.0000 \\
\hline $2008-2012$ & $\begin{array}{l}0.8603 * * * \\
(15.61)\end{array}$ & $13.97 \%$ & 4.61 & 116 & 358.08 & 0.0000 \\
\hline Full Sample & $\begin{array}{l}0.3375^{* * *} \\
(4.80)\end{array}$ & $66.25 \%$ & 0.64 & 261 & 233.81 & 0.0000 \\
\hline
\end{tabular}

Regression results for the partial adjustment model:

$$
\operatorname{Lev}_{i, t+1}=\alpha+(1-\lambda) L e v_{i, t}+\lambda \beta_{1} X_{t}+\lambda \beta_{2} E E W A M B_{t}+\lambda \beta_{3} D W A M B_{t}+c_{i, t}+\varepsilon_{i, t+1}
$$

Where $\lambda$ is the SOA towards the target leverage, $c_{i, T}$ is the time-invariant unobserved variable (firm fixed effect) and $\varepsilon_{i, T+1}$ is an error term. The variables determining the firm's long-run target leverage and the SOA are: profitability, size, tangibility and un-weighted market-to-book, and these are defined in Table $1 . E E W A M B_{t}$ and $D W A M B_{t}$ are the Bruinshoofd and De Haan (2012) equity and debt timing measures respectively; these are defined in Table 1. Tstatistics are reported in parentheses. The markings $* * *, * *$ and $*$ on coefficient estimates denote significant differences from zero at the levels of $1 \%, 5 \%$, and $10 \%$ respectively. The implied half-life is calculated as: half life $=\log (0.5) / \log (1-\lambda)$. Model specifications are shown under fit statistics. 
Table 5. Robustness Test: The Impact of Separate Equity and Debt Market Timing Measures on Capital Structure Regressions

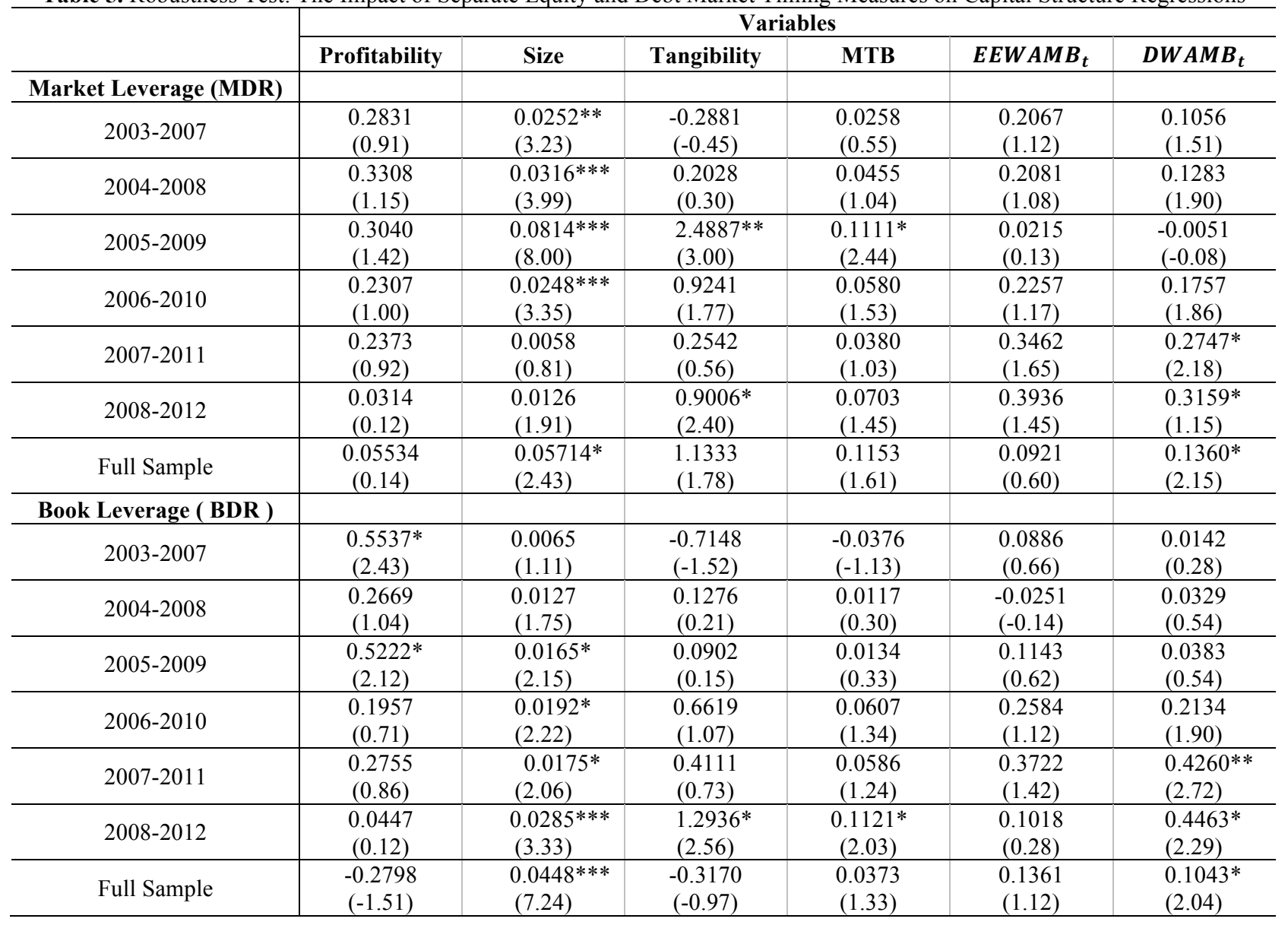


(Table 5 Continued)

\begin{tabular}{|c|c|c|c|c|c|c|}
\hline & \multicolumn{3}{|c|}{$\begin{array}{c}\text { Speed of Adjustment } \\
\end{array}$} & \multicolumn{3}{|c|}{ Fit Statistics } \\
\hline & $\begin{array}{c}\text { Lev_t+1 } \\
\text { Coefficient }\end{array}$ & SOA $(\lambda)$ & $\begin{array}{c}\begin{array}{c}\text { Half-life } \\
\text { (years) }\end{array} \\
\end{array}$ & Obs & Wald Chi2 & Prob $>$ Chi2 \\
\hline \multicolumn{7}{|c|}{ Market Leverage (MDR) } \\
\hline $2003-2007$ & $\begin{array}{l}0.7398^{* * * *} \\
(9.70)\end{array}$ & $26.02 \%$ & 2.30 & 140 & 245.56 & 0.0000 \\
\hline 2004-2008 & $\begin{array}{l}0.7338 * * * \\
(11.41)\end{array}$ & $26.62 \%$ & 2.24 & 140 & 283.30 & 0.0000 \\
\hline $2005-2009$ & $\begin{array}{l}0.2842 * * * \\
(3.61)\end{array}$ & $71.58 \%$ & 0.55 & 140 & 286.65 & 0.0000 \\
\hline $2006-2010$ & $\begin{array}{l}0.8476 * * * \\
(15.56)\end{array}$ & $15.24 \%$ & 4.19 & 140 & 476.30 & 0.0000 \\
\hline $2007-2011$ & $\begin{array}{l}0.9394 * * * \\
(18.48)\end{array}$ & $6.06 \%$ & 11.09 & 140 & 585.14 & 0.0000 \\
\hline $2008-2012$ & $\begin{array}{l}0.9334 * * * \\
(20.25)\end{array}$ & $6.66 \%$ & 10.06 & 112 & 699.10 & 0.0000 \\
\hline Full Sample & $\begin{array}{l}0.4556^{* * * *} \\
(6.21)\end{array}$ & $54.44 \%$ & 0.88 & 252 & 85.19 & 0.0000 \\
\hline \multicolumn{7}{|c|}{ Book Leverage ( BDR ) } \\
\hline $2003-2007$ & $\begin{array}{l}0.8574 * * * \\
(16.28)\end{array}$ & $14.26 \%$ & 4.51 & 140 & 400.98 & 0.0000 \\
\hline 2004-2008 & $\begin{array}{l}0.8363 * * * \\
(14.10)\end{array}$ & $16.37 \%$ & 3.88 & 140 & 295.84 & 0.0000 \\
\hline $2005-2009$ & $\begin{array}{l}0.8103 * * * \\
(14.17)\end{array}$ & $18.97 \%$ & 3.30 & 140 & 300.95 & 0.0000 \\
\hline $2006-2010$ & $\begin{array}{l}0.8358^{* * *} \\
(14.15)\end{array}$ & $16.42 \%$ & 3.86 & 140 & 282.30 & 0.0000 \\
\hline $2007-2011$ & $\begin{array}{l}0.8259 * * * \\
(14.96)\end{array}$ & $17.41 \%$ & 3.62 & 140 & 319.60 & 0.0000 \\
\hline $2008-2012$ & $\begin{array}{l}0.8065 * * * \\
(14.88)\end{array}$ & $19.35 \%$ & 3.22 & 112 & 341.54 & 0.0000 \\
\hline Full Sample & $\begin{array}{l}0.3022 * * * \\
(4.33)\end{array}$ & $69.78 \%$ & 0.58 & 252 & 381.42 & 0.0000 \\
\hline
\end{tabular}

Robustness Tests 1 and 2: The test results of both models are consistent with the main empirical results. Both MDR and BDR decrease with an increase in profitability, firm size, asset tangibility and from growth rate. Size is significant determinant of both MDR and BDR. In test 1, the market timing measure, $E F W A M B_{t}^{B W}$ is positively the MDR negatively correlated to the BDR. The correlations are however insignificant. The SOA of adjustment is within the range of test 1 results. The sample SOA is $62.10 \%$ (half-life of 0.71 years) for the MDR and $66.25 \%$ (0.64 years) for the BDR. In test 2, the market timing measures $E E W A M B_{t}$ and $D W A M B_{t}$ are all positively correlated to both the MDR and the BDR. The sample SOA is $54.44 \%$ (half-life of 0.88 years) for the MDR and $69.78 \%$ ( 0.58 years) for the BDR. These results reject the market timing hypothesis in the case of JSE-listed financial services firms. The correlations on profitability, size and tangibility and the positive SOA validate the dynamic trade-off theory.

\section{CONCLUSION}

This study was aimed at testing the suitability of the three leading capital structure theories in explaining the observed capital structures of financial services firms listed on the JSE. The theories tested were the dynamic tradeoff, pecking order and market timing theories. The results of the study can be summarised as follows. Both the Baker and Wurgler (2002) and the modified Bruinshoofd and De Haan (2012) market timing measures are positively correlated to the MDR and the BDR. The correlations are however insignificant in all cases. Firm profitability, size, tangibility and growth rate all positively correlated to the MDR and the BDR. The firms have a positive SOA towards the optimal capital structure. In the MDR regressions, the market timing measures have an insignificant impact on the firms' SOA towards the target leverage. The measures however increase the SOA towards the target 
leverage in the BDR regressions. The results are robust. These results reject both the pecking order and market timing hypotheses. Stock performance and share returns thus play no role in the security issuance decisions of these firms. Except for the correlation between leverage and firm growth, the results strongly validate the dynamic tradeoff theory. The JSE-listed financial services firms have target optimal capital structures which they actively adjusts towards. The firms actively rebalance their capital structures towards the pre-defined optimal. These findings are also consistent with the buffer capital and optimal bank capital structure hypotheses.

The size of the sample was the main limitation of this study. There were only twenty-nine listed financial services firms with complete data for eight or more consecutive years during the period 2003 to 2012. The study can be repeated using the Common Equity Tier 1 capital (CET 1 capital) ratio instead of the MDR and the BDR.

\section{AUTHOR BIOGRAPHY}

Vusani Moyo is an Associate Professor at the University of Venda, South Africa. He obtained his Ph.D. (Financial Management Sciences), an MSc (Finance) and MBA (Finance) from the University of Pretoria, University of Leicester School of Management and the University of Manchester Business School respectively. His current research interests are capital structure of African financial and non-financial firms, cash flow sensitivity of cash, investment cash flow sensitivity of cash, cost of capital, firm valuation and dividend policy.

\section{REFERENCES}

Allen, F.C., Carletti, E. \& Marquez, R. (2011). Credit market competition and capital regulation. The Review of Financial Studies, 24(4):983-1018.

Alti, A. (2006). How persistent is the impact of market timing on capital structure? The Journal of Finance, 61(4):1681-1710.

Amidu, M. (2007). Determinants of capital structure of banks in Ghana: an empirical approach. Baltic Journal of Management, 2(1):67-79.

Anderson, T.W. \& Hsiao, C. (1981). Estimation of dynamic models with error components. Journal of the American Statistical Association, 76(375):598-606.

Arellano, M. \& Bond, S. (1991). Some tests of specification for panel data: Monte Carlo evidence and an application to employment equations. Review of Economic Studies, 58(2):277-297.

Baker, M. \& Wurgler, J. (2002). Market timing and capital structure. The Journal of Finance, 57(1):1-32.

Barclay, M.J. \& Smith, C.W. (2005). The capital structure puzzle: the evidence revisited. Journal of Applied Corporate Finance, $17(1): 8-17$.

Barrios, V.E. \& Blanco, J.M. (2003). The effectiveness of bank capital adequacy regulation: a theoretical and empirical approach. Journal of Banking \& Finance, 27(10):1935-1958.

Baxamusa, M. (2011). How well do market timing, catering, and classical theories explain corporate decisions? Journal of Financial Research, 34(2):217-239.

Berger, A.N., De Young, R., Flannery, M.J., Lee, D. \& Oztekin, O. (2008). How do large banking organisations manage their capital ratios? Journal of Financial Services Research, 34:123-149.

Berger, A.N., Herring, R.J. \& Szego, G.P. (1995). The role of capital in financial institutions, Journal of Banking \& Finance, 19(3-4):393-430.

Bessler, W., Drobetz, W. \& Kazemieh, R. (2011). Factors affecting capital structure decisions. In: Baker, H.K \& Martin, G.S. (eds.) Capital structure and corporate financing decisions: theory, evidence, and practice. New Jersey: John Wiley.

Blundell, R. \& Bond, S. (1998). Initial conditions and moment restrictions in dynamic panel data models. Journal of Econometrics, 87(1):115-143.

Bougatef, K. \& Chichti, J.E. (2010). Equity market timing and capital structure: Evidence from Tunisia and France. International Journal of Business and Management, 5(10):167-177.

Bruinshoofd, W.A. \& De Haan, L. (2012). Market timing and corporate capital structure: A transatlantic comparison. Applied Economics, 44(28):3691-3703.

Bruno, G.S.F. (2005). Approximating the bias of the LSDV estimator for dynamic unbalanced panel data models. Economics Letters, 87(3):361-366.

Burch, T.R., Christie, W.G. \& Nanda, V. (2004). Do firms time equity offerings? Evidence from the 1930s and 1940s. Financial Management, 33(1):5-23.

Byoun, S. (2008). How and when do firms adjust their capital structures towards target leverage? The Journal of Finance, 63(6):3069-3096.

Campello, M. \& Giambona, E. (2013). Real assets and capital structure. Journal of Financial and Quantitative Analysis, 48(5):1333-1370. 
Dang, V.A. (2013). Testing capital structure theories using error correction models: evidence from the UK, France and Germany. Applied Economics, 45(2):171-190.

Dang, V.A, Kim, M. \& Shin, Y. (2012). Asymmetric capital structure adjustments: new evidence from dynamic panel threshold models. Journal of Empirical Finance, 19(4):465-482.

De Angelo, H. \& Masulis, R.W. (1980). Optimal capital structure under corporate and personal taxation. Journal of Financial Economics, 8(1):3-39.

De Bie, T. \& De Haan, L. (2007). Market timing and capital structure: evidence from Dutch firms. De Economist, 155(2):183206.

De Wet, J.H. (2014). Capital structure and regulation implications for South African banks. Corporate Ownership Control, 11(1):797-808.

Diamond, D. \& Rajan, R. (2000). A theory of bank capital, The Journal of Finance, 55(6):2431-2465.

Drobetz, W. \& Wanzenried, G. (2006). What determines the speed of adjustment to the target capital structure? Applied Financial Economics, 16(13):941-958.

Elliott, W.B., Koeter-Kant, J. \& Warr, R.S. (2008). Market timing and the debt-equity choice. Journal of Financial Intermediation, 17(2):175-197.

Elsas, R. \& Florysiak, D. (2011). Heterogeneity in the speed of adjustment toward target leverage. International Review of Finance, 11(2):181-211.

Elsas, R. \& Florysiak, D. (2013). Dynamic capital structure adjustment and the impact of fractional dependent variables. Working Paper, Institute of Finance and Banking, University of Munich, 1-44. [Online] Available from: http://papers.ssrn.com/sol3/papers.cfm?abstract_id=1632362_[Downloaded: 2014-09-16].

First Rand Group Limited. (2013). Annual integrated report, 1-456. [Online] Available from: http://www.firstrand.co.za/InvestorCentre/FirstRand\%20Bank\%20Limited\%20Annual\%20Reports\%202012/2013\%20 FSR\%20annual\%20integrated\%20report.pdf [Downloaded: 2014-09-16].

Fischer, E.O., Heinkel, R. \& Zechner, J. (1989). Dynamic capital structure choice: theory and tests. The Journal of Finance, 44(1):19-40.

Flannery, M. (1994). Debt maturity and the deadweight cost of leverage: optimally financing banking firms, The American Economic Review, 84(1):320-331.

Flannery, M. \& Rangan, K. (2006). Partial adjustment toward target capital structures. Journal of Financial Economics, 79(3):469-506.

Frank, M.Z. \& Goyal, V.K. (2004). The effect of market conditions on capital structure adjustment. Finance Research Letters, $1(1): 47-55$.

Frank, M.Z. \& Goyal, V.K. (2009). Capital structure decisions: which factors are reliably important? Financial Management, $38(1): 1-37$.

Furfine, C. (2001). The interbank market during a crisis, Bank for International Settlements Working Papers, WP 99, 1-19. [Online] Retrieved from: http://www.bis.org/publ/work99.htm [Downloaded: 2014-09-16].

Goldstein, R., Ju, N. \& Leland, H. (2001). An EBIT-based model on dynamic capital structure. The Journal of Business, 74(4):483-512.

Graham, J.R. (2000). How big are the tax benefits of debt? The Journal of Finance, 55(5):1901-1941.

Graham, J.R. \& Harvey, C.R. (2001). The theory and practice of corporate finance: evidence from the field. Journal of Financial Economics, 60(2-3):187-243.

Gropp, R. \& Heider, F. (2010). The determinants of bank capital structure, Review of Finance, 14(4):587-622.

Harvey, C.R., Lins, K.V. \& Roper, A.H. (2004). The effect of capital structure when expected agency costs are extreme. The Journal of Financial Economics, 74(1):3-30.

Heid, F., Porath, D. \& Stolz, S. (2004). Does capital regulation matter for bank behaviour? Evidence from German savings banks, Deutsche Bundesbank Discussion Paper, Series 2: Banking and Financial Supervision, No. 03/2004, 1-24. [Online] Retrieved from: http://econstor.eu/bitstream/10419/19730/1/200403dkp_b.pdf [Downloaded: 2014-09-16].

Hovakimian, A. \& Li, G. (2011). In search of conclusive evidence: how to test for adjustment to target capital structure. Journal of Corporate Finance, 17(1):33-44.

Hovakimian, A., Opler, T. \& Titman, S. (2002). The capital structure choice: new evidence for a dynamic trade-off model. Journal of Applied Corporate Finance, 15(1):24-30.

Huang, R. \& Ritter, J.R. (2009). Testing theories of capital structure and estimating the speed of adjustment. Journal of Financial and Quantitative Analysis, 44(2):237-271.

Jensen, M.C. (1986). Agency costs of free cash flow, corporate finance and takeovers. The American Economic Review, 76(2):323-329.

Jensen, M.C. \& Meckling, W.H. (1976). Theory of the firm: managerial behaviour, agency costs and ownership structure. Journal of Financial Economics, 3(4) 305-360.

Jenter, D. (2005). Market timing and managerial portfolio decisions. The Journal of Finance, 60(4):1903-1949.

Kayhan, A. \& Titman, S. (2007). Firms' histories and their capital structures. Journal of Financial Economics, 83(1):1-32.

Kisgen, D. J. (2007). The influence of credit ratings on corporate capital structure decisions. Journal of Applied Corporate Finance, 19(3):65-73. 
Korajczyk, R.A., Lucas, D.J. \& McDonald, R.L. (1992). Equity issues with time-varying asymmetric information. The Journal of Financial and Quantitative Analysis, 27(3):397-417.

Leary, M.T. \& Roberts, M.R. (2005). Do firms rebalance their capital structures? The Journal of Finance, 60(6):2575-2619.

Lemmon, M.L. \& Zender, J.F. (2010). Debt capacity and tests of capital structure theories. Journal of Financial and Quantitative Analysis, 45(5):1161-1187.

Lim, T.C. (2012). Determinants of capital structure empirical evidence from financial services listed firms in China, International Journal of Economics and Finance, 4(3):191-203.

Lindquist, K. (2004). Bank's buffer capital: how important is risk, Journal of International Money and Finance, 23(3):493-513.

Lucas, D.J. \& McDonald, R.L. (1990). Equity issues and stock price dynamics. The Journal of Finance, 45(4):1019-1043.

Mahajan, A. \& Tartaroglu, S. (2008). Equity market timing and capital structure: International evidence. Journal of Banking \& Finance, 32(5):754-766.

Marcus, A.J. (1984). Deregulation and bank financial policy, Journal of Banking \& Finance, 8(4):557-565.

Milne, A. \& Whalley, A.E. (2001). Bank capital regulation and incentives for risk-taking, Cass Business School Working Paper, 1-52. . [Online] Retrieved from: http://papers.ssrn.com/sol3/papers.cfm?abstract_id=299319 [Downloaded: 2014-09$16]$.

Modigliani, F. \& Miller, M.H. (1963). Taxes and the cost of capital: a correction. American Economic Review, 53(3):433-443.

Moyo (2014). What drives security issuance decisions of firms listed on the Johannesburg Stock Exchange: Market timing or dynamic trade-off theory or both? Working Paper 001, Universityn of Veda.

Moyo, V., Wolmarans, H. \& Brümmer, L. (2013). Trade-off or pecking order hypothesis? Evidence from South African manufacturing, mining and retail firms, International Business \& Economics Research Journal, 12(8):927-944.

Mukherjee, S. \& Mahakud, J. (2012). Are trade-off and pecking order theories of capital structure mutually exclusive? Evidence from Indian manufacturing firms. Journal of Management Research, 12(1):41-55.

Myers, S.C. (1977). Determinants of corporate borrowing. Journal of Financial Economics, 5(1):146-175.

Myers, S.C. (1984). The capital structure puzzle. The Journal of Finance, 39(3):575-592.

Myers, S.C. (2008). Financing of corporations. In: Constantinides, G.M., Harris, M. \& Stulz, R.M. (eds.) Handbook of the economics of finance, $1 \mathrm{~A}$. Amsterdam: North-Holland.

Myers, S.C. \& Majluf, N.S. (1984). Corporate financing and investment decisions when firms have information that investors do not. Journal of Financial Economics, 13(2):187-221.

Myers, S. and Rajan, R. (1998). The paradox of liquidity, Quarterly Journal of Economics, 113(3):733-771.

Nedbank Group Limited. (2013). Annual integrated report. [Online] Available from: http://www.nedbankgroup.co.za/financial/Nedbank_ar2013/downloads/NedbankIR2013.pdf [Downloaded: 2014-09$16]$.

Octavia, M. \& Brown, R. (2008). Determinants of bank capital structure in developing countries: regulatory capital requirement versus the standard determinants of capital structure, The University of Melbourne Working Paper, 1-53. [Online] Retrieved from: http:/www.efmaefm.org/0EFMAMEETINGS/EFMA\%20ANNUAL\%20MEETINGS/2008athens/Brown.pdf [Downloaded: 2014-09-16].

Ramjee, A. \& Gwatidzo, T. (2012). Dynamics in capital structure determinants in South Africa. Meditari Accountancy Research, 20(1):52-67.

Rime, B. (2001). Capital requirements and bank behaviour" empirical evidence for Switzerland, Journal of Banking \& Finance, 25(4):789-805.

Shivdasani, A. \& Zenner, M. (2005). How to Choose a Capital Structure: Navigating the Debt-Equity Decision. Journal of Applied Corporate Finance, 17(1):26-35.

Shyam-Sunder, L. \& Myers, S.C. (1999). Testing static trade-off against pecking order models of capital structure. Journal of Financial Economics, 51(2):219-244.

Shrieves, R.E. \& Dahl, D. (1992). The relationship between risk and capital in commercial banks, Journal of Banking \& Finance, 16(2):439-457.

Spiess, K.D. \& Affleck-Graves, J. (1999). The long-run performance of stock returns following debt offerings. Journal of Financial Economics, 54(1):45-73.

Standard Bank Group Risk and capital management report and annual financial statements. (2013). [Online] Available from: http://reporting.standardbank.com/wp-content/uploads/2014/05/SBG-RCM-and-AFS-2013-FINAL2.pdf_[Downloaded: 2014-09-16].

Stulz, R.M. (1990). Managerial discretion and optimal financing policies. Journal of Financial Economics, 26(1):3-27.

Titman, S. \& Wessels, R. (1988). The determinants of capital structure choice. The Journal of Finance, 43(1):1-19.

Tong, G. \& Green, C.J. (2005). Pecking order or trade-off hypothesis? Evidence on the capital structure of Chinese companies. Journal of Applied Economics, 37(19):2179-2189.

Walker, M.D. \& Yost, K. (2008). Seasoned equity offerings: What firms say, do, and how the market reacts. Journal of Corporate Finance, 14(4):376-386. 